\title{
Review of Another Paradise
}

\author{
Btihaj Ajana
}

Received: 25 May 2009 / Accepted: 14 June 2009 /Published online: 1 October 2009

(C) Identity Journal Limited 2009

Set against the backdrop of the controversial UK Identity Card scheme, Sayan Kent's recent play Another Paradise (2009) conjures up a future dystopian image of a biometrically-controlled Britain in which every citizen is reliant on biometric technology, ID cards and national databases not only as a means for functioning in everyday life, but more so as a prerequisite for being able to "count" as a person at all.

Kent's message is trenchant and clear: with this extremely technocratic trend, toward which the world is apparently heading, comes a loss of agency, individuality, liberty and human touch. The play, as such, acts as a mouthpiece for conveying some of the major debates surrounding the adoption of biometric ID cards and highlighting the potentially dangerous ramifications of over-relying on technology for governing society. Much of these alarming concerns and potential implications are explored, somewhat satirically but nonetheless seriously, through the characters' manipulated, re-appropriated, mistaken, lost or stolen identities as well as through the concrete situations in the midst of which they find themselves as a result.

\section{Who are you?}

As a thesis play, Another Paradise raises many challenging and timely questions, questions to do with the growing state surveillance, the neurotic securitisation of life, the erosion of civil liberties, and the systematic exclusion of those deemed not worthy of belonging. But beside these empirically embedded concerns, there is a highly philosophical question underpinning the play. That is, the age-old question "who are you?", which warrants some discussion.

B. Ajana $(\bowtie)$ BIOS Centre, London School of Economics, Tower 2, 11th Floor Houghton Street, London WC2A 2AE, UK

e-mail: b.ajana@1se.ac.uk 
Although basic and commonplace in itself, the question "who are you?" remains as one of the most challenging, problematic, fluid and intricate questions to which neither the philosophical discourses of metaphysics nor the technologies and techniques of identification have been able to provide a fixed and conclusive answer. "Who are you?" is indeed 'an abyssal question', as Carl Schmitt (1950) put it. It is not because the word 'who' stands for something that is ineffable, unfathomable, unnameable and ungraspable, or something utterly secretive that only the 'self' can have an exclusive access to. Rather, it is because 'who' is that which indicates the incomparable uniqueness and the unrepeatable singularity of each and everyone (Nancy 2000). And in so doing, it can only yield a response that is destined to escape the linguistic confines of definition and challenge the technical mechanisms of recognition. Inexorably then, 'the moment we want to say who someone is, our very vocabulary leads us astray into saying what he is' (Arendt 1957: 181), that is, the attributes and qualities which act as the content of one's identity and function as qualifiers for membership, citizenship and so forth (see also Kottman 2000: viii; Butler 2005: 31; Cavarero 2000; Ricoeur 1992). The conflation of 'who' and 'what' is in fact an attestation to the inability of both philosophy and technology to fully capture the ambivalence and double-sided character of identity and to acknowledge the impossibility of fixing once and for all that which makes the person irreducibly unique and singular. In Another Paradise, this is expressed quite vehemently by one of the characters, Abigail Tomlin, whose identity is stolen and re-appropriated, and as a result is no longer able to prove who she is insofar as what she is (her name, her biometric information, etc.) does not match her file on the national database:

ABI: Don't think you know me because you know what washing powder I buy, or which TV channels I watch, or how many hotels I've stayed in. It's what that file doesn't tell you that counts. You might know how many lovers I've had but you don't know how much I loved them. You might know which brand of chocolate I buy, but you don't know what I taste when I eat it. You don't know my favourite joke, you don't know what cripples me with laughter and you'll never know which photograph I cry over. You think you know my political persuasions but you don't know what burns inside me, what eats me up, what consumes me with passion, what makes me who I am. You...will never know me.

Indeed, what biometric technology can capture and make epistemologically knowable and technically available about the person is merely the 'what' aspect of identity: physical characteristics, behavioural traits, institutionally assigned attributions, etc. This, of course, only constitutes half of the story. What remains inaccessible through and untellable by biometrics is precisely that uniqueness of the 'who' wherein reside the person's intentions, values, beliefs, desires, and resistance itself. In this sense, Abigail's defiant statement "You...will never know me" is a reminder that biometrics' overzealous quest for capturing the uniqueness of singularity and accessing the nexus of 'whoness' is doomed to failure. For the very premise of biometric technology is based upon a partial and restricted understanding of identity that is informed by hyper-scientific discourses and technical practices 
whose aim is to 'simplify' the meaning and function of identity, and to 'purge' it from its ambivalent, contextual, contingent and subjective dimension. And what comes part and parcel of this technologisation of identity is the growing indifference toward the embodied person herself; the bypassing of her 'self-attesting' story in favour of capturing, measuring and storing digital templates of her biological data. Such a process partakes of what we may call, following on from Gilles Deleuze (1992), the dividuation of individuals. That is to say, the practice by which they are turned into 'dividuals'; a series of abstract bits and digits scattered around databases and identified by their profiles, pin numbers, consumer data, credit scoring, etc., rather than their subjectivities (see also Rose 1999 and Haggerty and Ericson 2000). As illustrated by this exchange between the characters Lisa Grundy (a customer services employee at the Alien Registration Office) and Enoch Dawes (an accountant who subsequently becomes a 'nobody' after his identity was stolen):

LISA: Do you find that you are a black and white person?

Clarity. Polarity. Contrast. Definitives.

ENOCH: Clarity?

LISA: As opposed to subtle, nebulous, fluid, ambidextrous.

ENOCH: Ambidextrous?

LISA: Yes or no?

ENOCH: Like you're a somebody and I'm a nobody?

LISA: Think of your ID card as the portal to your digital soul. It links you to who you are. As long as you are attached to a corresponding file on the database the card could say you were a mouse and I would believe it. Even if you didn't look like a mouse. Which you do, slightly. Even if you stood in front of me as you are and your data told me you were Monty the Mouse I would accept that as true. I would greet you as Monty and offer you a piece of cheese.

And again, as the character Captain Fisher (a female police captain specialising in internal security) puts it:

FISHER: Mrs Tomlin, you have to appreciate that I work in a grey area where people say all sorts of things. My job is not to take people on their word but on what their card verifies. Verify, to establish the truth, accuracy, reality. Verificare from the Latin verus, true. That's why I like it. I don't have to make difficult decisions. I can leave that to the judges and politicians.

Seen in this light, the power struggle, which unfolds in the domain of biometric technology and ID cards, can then be articulated as a struggle around, and at times between, two competing onto-epistemic registers of truth. On the one hand, there is the truth that is distilled from the person's bodily particularities with the aim to officially establish an institutionally governable and controllable identity- the one that is 'required by state bureaucracy: a stable, objective, unambiguous and thinglike identity' (Aas 2006: 147). On the other hand, there is the truth that stems from the narrative, biographic and self-attesting dimension of identity, i.e. from the person's story. While the former can be seen as belonging to the realm of the 'what', the latter is an expression of the dimension of 'who'. Increasingly, and especially 
within the rationality underpinning biometric technology and identity cards, there is a fundamental epistemological suspicion towards the story, and with it, the growing occlusion of selfhood and the redundancy of 'whoness' itself. Therefore,

[a] talking individual, who owns the body, is in fact seen as unnecessary and, even more importantly, insufficient for identification. Now only the body can talk in the required ways, through the unambiguous and cryptic language of codes and algorithms. When a body provides the password, a world of information opens. Databases begin to talk. On the other hand, when the individual talks, the words are only met with suspicion.

ibid.: 154

It should be noted at this point that the distinction between the 'what' and the 'who' aspects of identity is not to be understood as a sharp and clear-cut dichotomy. For in the concrete sense, these dimensions continuously interact with each other and in ways that are by no means mutually exclusive: institutional identity ascriptions (citizenship, membership, etc.) certainly shape some aspects of the life story of the person, just as the narrative accounts one gives about oneself when asked the question "who are you?" may contain, affect and be affected by, elements that belong to the sphere of the 'what' (as in the case with the narrative identity of the 'asylum seeker' and the 'refugee'). Yet and in terms of biometrics, there is an evident imbalance in the relationship that mediates between these two dimensions of identity insofar as the knowledge that is produced through biometric procedures is not a knowledge based on 'mutual communication', but on 'one-way observation. It is clearly knowledge marked by a power relation' (ibid.: 153). It thus favours the forms and discourses of truth that emerge out of official sources and technical operations rather than from personal accounts. In Another Paradise, this is demonstrated, with much satire, through various situations whereby the 'card' and the 'file' end up overriding the 'life' and the personal reality of the characters by forcing them to adjust to the new identities they are officially assigned. For instance, Enoch Dawes who adopts the re-appropriated identity of Abigail Tomlin, gets treated as Abigail by everyone (including Abigail's husband) despite the visual evidence of his gender:

LISA: Look, this is a good ID. You'll love it. Once you get used to it. Now go home. (Hands him the printout). There's your new address. Bank details. Potted history, employment record. National insurance number. Date of birth. All sort of interesting things.

ENOCH: I can't just walk into another life.

LISA: This is you now.

ENOCH: Look at it. No one will believe me.

LISA: Of course they'll believe you.

ENOCH: But I've stolen somebody.

LISA: You can't do anything about it now. Cheer up. It could have been a lot worse. I'm glad it's all worked out. Enjoy your new life, Mrs Abigail Tomlin. Abi. 


\section{Coventry, a non-place}

LISA: ...Every sovereign state has its Coventry. It's the price we pay for freedom.

Coventry features in the play as the place where the unidentified/unidentifiable and the biometrically unqualified are sent. It is reminiscent of what Giorgio Agamben (1998) refers to as the 'space of exception'; a peculiar non-place which is a byproduct of too much organisation and excessive orderliness. It exists both inside and outside the state: inside, in terms of its physical presence that marks its 'inclusion' within the state's boundaries, and outside insofar as it is 'excluded' from its regular social and juridico-political procedures and structure. It is like a 'mezzanine space of sovereignty' (Nyers 2003: 1080) whose exclusion in an 'inclusive exclusion' (an exceptio) and whose function is to contain those who are categorised as 'noncitizens'; those who are '[c]onstituted as threshold political beings [... and] defined precisely through their liminal status that places them on the outskirts of the community' (Zylinska 2004: 530). In Another Paradise, the non-place aspect and the exceptio character of Coventry are represented in terms of its absence on the official map, as well as through the kind of activities performed within it and the type of people who dwell in it:

ENOCH: I stole a map.

LISA: I don't need to know that.

ENOCH: Coventry isn't on it. It's just a blur, an MOD restricted area. Look.

(Thrusts a map at her.) No Coventry. You told me it existed.

LISA: Coventry?

ENOCH: A cash economy no questions and no cannibalism.

LISA: A state of mind.

ENOCH: So I went to the blur.

LISA: It's just a saying, being sent to Coventry.

ENOCH: I've been to Coventry ... Why is it a blur? Tell me.

LISA: It doesn't exist.

ENOCH: Coventry does exist. It's real. What are you hiding?

LISA: When the biometric identity scheme phase 3 was instigated, the whole population was finally put onto the national database. But there were many people living in this country who didn't fulfil the exacting requirements of citizenship. So, the government, having invested billions in the program, requisitioned a small city in the Midlands to dump the leftovers in. Coventry, a haven for aliens.

According to Agamben (1998: 109), what binds the life of those considered as non-citizens to sovereign power is the notion of the 'ban'; a relation of exception that is both inclusive and exclusive of life and in which the 'banned' is made subject to the rule of the law while being excluded from it and abandoned by it: ' $\mathrm{He}$, who has been banned is not, in fact, simply set outside the law and made indifferent to it, but rather abandoned by it, that is, exposed and threatened on the threshold in which life and law, outside and inside, become indistinguishable' (ibid.: 28). 
ENOCH: They just left them there?

LISA: Up the creek without a paddle.

ENOCH: No communication with the outside world.

LISA: It's shielded. A measure of containment.

ENOCH: And no one has to prove who they are, just names.

LISA: Just names, can you imagine?

ENOCH: Nothing but a blur.

Importantly, this rationality of abandonment and exception is not tantamount to the casting out of politics or the cancellation of what is deemed as the norm. Instead it is regarded as an integral part of 'normal politics' itself and a condition of possibility for its actualisation and organisation. As Rajaram and Grundy-Warr (2004: 34, 36) argue, 'the condition of exemption by which the normal political space is declared entails that the norm is dependent on its exempted other [...] it is through the appropriation and control of the excluded, in effect its inclusion with its threat ameliorated, that the sovereign law maintains itself'. Lisa Grundy's abovementioned statement, about Coventry being the price one pays for freedom, is indeed indicative of the intimate and co-dependent relationship between exception and the norm, between the sovereign inside and its (imagined) dangerous outside. It also echoes the neoliberal modality of 'governing through freedom', which takes as its premise the logic of individual 'autonomisation', that is, the governing of individuals as 'subjects of freedom' (see Rose 1999; Miller and Rose 2008; van Munster 2005). Freedom, as such, is seen as both an 'objective' to strive for and a 'resource' to be enabled and managed through the myriad of techniques and technologies such as biometrics and ID cards. Concurrently, in the neoliberal style of governing, freedom also involves the control and monitoring of that which poses a (potential) threat to its exercise, and the (inclusive) exclusion of those who cannot be 'entrusted to enjoy' freedom (van Munster 2005: 6). Coventry, in this regard, can be seen as an extension to such techniques and strategies, and a constitutive element to the maintenance of the norm. This, insofar as it represents a means by which residual otherness and its perceived dangerousness are regulated and contained with the aim to facilitate the exercise of freedom (of access and mobility, for instance) for those who qualify as belonging citizens and to minimise the supposed disturbance and threat of those who do not.

Perhaps the play's most sinister message, and one that mostly resonates with Agamben's alarming accounts, is to do with the fine and fragile line that distinguishes between citizens and non-citizens. In a society that is overly dependent on technology rather than politics for organising the life of its inhabitants, there is always the looming danger of turning exception into the norm, rendering every citizen as a potential non-citizen; every identity as a suspect identity, and making the space of exception, such as that of Coventry, the fundamental paradigm of the city itself.

Yet despite this bleak picture and ominous accounts, both Kent's play and Agamben's thesis manage to leave a room for hope and potentiality. Curiously, it seems that it is precisely within these zones of indistinction (between exception and norm, life and non-life, citizen and non-citizen, city and camp, etc.) that the possibility for resistance might exist and that the resuscitation of the political might take place. For 
instance, Coventry, against all odds, becomes the sole place where a sense of community and human touch still subsist, unfettered by the need for identification and unburdened by the imperative to constantly prove one's entitlements.

To a certain extent, then, Another Paradise has succeeded in interweaving the different concerns surrounding biometric technology and ID cards together with the enduring philosophical questions regarding identity, rights and belonging. And in this sense, it has undoubtedly done what a thesis play has to do: exposing some of the most pertinent, problematic and controversial socio-political issues of our time, and stimulating further thinking and debate.

\section{References}

Aas KF. 'The body does not lie': identity, risk and trust in technoculture. Crime Media Culture. 2006;2:2. Agamben G. Homo Sacer: Sovereign Power and Bare Life, Stanford University Press, 1998.

Arendt H. The human condition. Chicago: Chicago University Press; 1957.

Butler J. Giving an account of oneself. New York: Fordham University Press; 2005.

Cavarero A. Relating narratives: storytelling and selfhood. London and New York: Routledge; 2000.

Deleuze G. Postscript on the Societies of Control. http://pdflibrary.files.wordpress.com/2008/02/ deleuzecontrol.pdf, 1992.

Haggerty KD, Ericson RV. The Surveillant Assemblage. Br J Sociol. 2000;51:4.

Kent S. Another Paradise. Kali Theatre Production, 2009.

Kottman PA. Translator Introduction. In Relating Narratives: Storytelling and Selfhood, Cavarero. A., London: Routledge, 2000.

Miller P, Rose N. Governing the present: administering economic, social and personal life. Cambridge: Polity; 2008.

Nancy J-L. Being singular plural. Stanford: Stanford University Press; 2000.

Nyers P. Abject Cosmopolitanism: the politics of protection in the anti-deportation movement. Third World Q. 2003;24:6.

Rajaram PR, Grundy-Warr C. The irregular migrant as homo sacer: migration and detention in Australia, Malaysia, and Thailand. Int Migr. 2004;42:1.

Ricoeur P. Oneself as another. Chicago: The University of Chicago Press; 1992.

Rose N. Powers of Freedom: Reframing political thought. Cambridge: Cambridge University Press; 1999. Schmitt C. Ex capitivitate salus. Cologne: Greven Verlag; 1950.

Van Munster R. The EU and the Management of Immigration Risk in the Area of Freedom, Security an Justice. University of Southern Denmark Political Science Publications, 2005.

Zylinska J. The universal acts. Judith Butler and the biopolitics of immigration. Cult Stud. 2004;18:4. 